\title{
ANALISIS HARGA SAHAM PT. ANTAM tbk BERDASARKAN HARGA EMAS DAN NILAI TUKAR RUPIAH TERHADAP DOLAR MENGGUNAKAN MODEL AUTOREGRESSIVE DISTRIBUTED LAG
}

\author{
Lexy J. Sinay ${ }^{1}$, Fitri R. N. Tihurua ${ }^{2}$, Dorteus L. Rahakbauw ${ }^{3}$ \\ 1, 2,3 Jurusan Matematika FMIPA, Universitas Pattimura \\ Jalan Ir. M. Putuhena, Kampus Unpatti, Poka, Ambon, Indonesia \\ e-mail: 1ㄴexy.jz@gmail.com; ${ }^{2}$ frahayumaliek@gmail.com; ${ }^{3}$ lodewyik@gmail.com
}

\begin{abstract}
Abstrak
Saham adalah secarik kertas yang menunjukkan hak pemodal yaitu pihak yang memiliki kertas tersebut untuk memperoleh bagian dari prospek atau kekayaan organisasi yang menerbitkan sekuritas tersebut, dan berbagai kondisi yang memungkinkan pemodal tersebut menjalankan haknya. PT. ANTAM tbk adalah sebuah perusahaan pertambangan di Indonesia yang terdiversifikasi dan terintegrasi secara vertikal yang berorientasi dibidang ekspor. Kegiatan perusahaan ini mencakup eksplorasi, penambangan, pengolahan serta pemasaran dari komoditas bijih nikel, feronikel, emas, perak, bauksit dan batubara. Dengan menggunakan model ARDL peneliti ingin mengetahui hubungan antara harga saham PT. ANTAM tbk dengan harga emas dan nilai tukar dolar terhadap rupiah. Model $A R D L$ adalah model yang digunakan untuk melihat adanya pengaruh variabel dependen $(Y)$ dan variabel independen $(X)$ dari waktu ke waktu termasuk pengaruh varibel dependen $(Y)$ dari masa lalu terhadap nilai varibel dependen $(Y)$ masa sekarang. Dari hasil pengujian Bounds pada model $A R D L(2,5,5)$ untuk masing-masing tingkat kepercayaan 90\%, 95\%, 97,5\%, dan 99\%, diperoleh bahwa nilai Statistik-F yaitu 2,6148 lebih kecil dari pada nilai kritis batas bawah (lower bound), maka hipotesis nol diterima sehingga dapat dikatakan bahwa tidak terdapat hubungan jangka panjang (tidak terkointegrasi) pada model $A R D L(2,5,5)$. Dengan demikian, dalam jangka pendek harga emas dan nilai tukar dolar terhadap rupiah mempengaruhi harga saham PT. ANTAM tbk.
\end{abstract}

Kata Kunci : Autoregressive Distributed Lag (ARDL), kointegrasi, PT. ANTAM tbk.

\section{STOCK PRICE ANALYSIS PT. ANTAM tbk BASED ON GOLD PRICE AND DOLLAR EXCHANGE RATE TO RUPIAH USING AUTOREGRESSIVE DISTRIBUTED LAG MODEL}

\begin{abstract}
Stock is a piece of paper indicating the investor's right that the party owns the paper to obtain part of the prospect or wealth of the organization issuing the securities, and the conditions under which the investor may exercise his right. PT. ANTAM tbk is a diversified and vertically integrated mining company oriented in the field of export. The company's activities include exploration, mining, processing and marketing of nickel, ferronickel, gold, silver, bauxite and coal commodities. By using ARDL model the researcher wanted to know the relation between share price of PT. ANTAM tbk with gold price and dollar exchange rate against rupiah. The ARDL model is a model used to see the effect of the dependent variable (Y) and the independent variable (X) over time including the dependent variable influence $(Y)$ from the past on the value of the current dependent variable (Y). From the Bounds test result on the ARDL model (2.5.5) for each of $90 \%, 95 \%, 97.5 \%$, and $99 \%$ confidence levels, it was found that the F-Statistic Value of 2.6148 is less than the value critical lower bound, then the null hypothesis is accepted so that it can be said that there is no long-term relationship (unintegrated) on the ARDL model (2.5.5). Thus, in the short term the price of gold and the dollar exchange rate against the rupiah affect the stock price of PT. ANTAM tbk.
\end{abstract}

Keywords: Autoregressive Distributed Lag (ARDL), cointegration, PT. ANTAM tbk. 


\section{Pendahuluan}

Saham merupakan pembukuan atau satuan nilai dalam berbagai instrumen finansial yang mengacu pada bagian kepemilikan sebuah perusahaan. Menurut Husnan Suad, saham adalah secarik kertas yang menunjukkan hak pemodal yaitu pihak yang memiliki kertas tersebut untuk memperoleh bagian dari prospek atau kekayaan organisasi yang menerbitkan sekuritas tersebut, dan berbagai kondisi yang memungkinkan pemodal tersebut menjalankan haknya [1].

Perkembangan harga saham sendiri selalu menjadi obyek yang sangat menarik untuk diprediksi dan dianalisis. PT. Aneka Tambang tbk atau yang biasa disebut PT. ANTAM tbk adalah sebuah perusahaan pertambangan di Indonesia yang terdiversifikasi dan terintegrasi secara vertikal yang berorientasi dibidang ekspor. Wilayah operasi ANTAM tersebar diseluruh Indonesia. Kegiatan perusahaan ini mencakup eksplorasi, penambangan, pengolahan serta pemasaran dari komoditas bijih nikel, feronikel, emas, perak, bauksit dan batubara.

Ada beberapa faktor yang dapat mempengaruhi harga saham suatu perusahaan, diantaranya adalah faktor harga emas (produksi) dan faktor nilai tukar mata uang (kurs). Selain dari faktor-faktor itu, ada juga kemungkinan harga saham suatu perusahaan dapat dipengaruhi oleh harga saham pada periode-periode lalu atau periode sebelumunya. Dengan menggunakan model Autoregrssive Distributed Lag (ARDL) peneliti ingin mengetahui tentang adanya hubungan antara harga emas dan nilai tukar mata uang terhadap harga saham PT. ANTAM tbk. Karena model ARDL adalah model yang menggabungkan model Autoregressive $(A R)$ dan model Distributed Lag $(D L)$, dimana model Autoregressive $(A R)$ sendiri adalah model yang menggunakan satu atau lebih data masa lalu dari variabel dependen $(Y)$ diantara variabel penjelas. Sedangkan model Distributed Lag (DL) adalah model regresi yang melibatkan data pada waktu saat ini (sekarang) dan waktu masa lalu (Lagged) dari variabel penjelas [2].

Dengan demikian dapat disimpulkan bahwa $A R D L$ adalah model yang digunakan untuk mengetahui pengaruh antara variabel dependen $(Y)$ dan independen $(X)$ dari waktu kewaktu, termasuk pengaruh variabel dependen $(Y)$ dari masa lalu terhadap nilai variabel dependen $(Y)$ masa sekarang.

\section{Metode Penelitian}

Data yang digunakan dalam penelitian ini adalah data sekunder. Penelitian ini mencakup data harga saham PT. ANTAM tbk, data harga emas, dan data harga dollar Amerika. Semua data yang diambil adalah data harian dan pengolahan data pada penelitian ini menggunakan Software E-views.

Variabel yang digunakan dalam penelitian ini ada tiga variabel, yang terdiri dari satu variabel dependen (Y) dan dua variabel independen (X). Ketiga variabel tersebut adalah sebagai berikut :

1. Variabel dependen (Y) yaitu harga saham PT. ANTAM tbk.

2. Variabel independen (X) yaitu faktor-faktor yang mempengaruhi harga saham PT. ANTAM tbk :

$X_{1}$ : Harga emas.

$X_{2}$ : Nilai tukar rupiah terhadap dolar Amerika.

Metode yang digunakan dalam penelitian ini yaitu mengumpulkan, mempelajari, dan menganalisis data ilmiah yang di peroleh dari bahan atau materi penelitian kemudian dipertanggungjawabkan secara ilmiah dalam bentuk skripsi. Adapun prosedur penelitian yang dilakukan adalah sebagai berikut:

1. Menentukan judul penelitian serta mencari literatur tentang Metode Autoregressive Distributed Lag (ARDL) dan informasi harga saham PT. ANTAM tbk

2. Menguji kestasioneran data menggunakan uji Augmented Dickey-Fuller Tes (ADF)

3. Menyeleksi lag untuk memperoleh order model menggunaknan Akaike Information Criteria (AIC)

4. Mengestimasi model ARDL

5. Pemeriksaan Diagnosa, meliputi: Uji Breusch-Godfrey Lagrange Multiplier (BGLM) dan Uji CUSUM dan CUSUM Square (CUSUMsq)

6. Menguji Bounds model ARDL dengan menggunakan uji statistik-F

7. Menginterpretasi model ARDL 


\section{Hasil Dan Pembahasan}

\subsection{Deskripsi Statistika}

Penelitian ini menggunakan data harian berupa data hari aktif dengan jumlah observasi adalah 2798 observasi, yaitu data harian pada periode 2 Januari 2007 - 28 September 2017. Deskripsi statistika untuk ketiga variabel yaitu, variabel harga saham PT. ANTAM tbk $(Y)$, variabel harga emas $\left(X_{1}\right)$ dan variabel nilai tukar dolar terhadap rupiah $\left(X_{2}\right)$ yang digunakan dapat dilihat pada tabel dan Grafik, berikut:

\section{Tabel 1. Deskripsi Statistika}

\begin{tabular}{|l|c|c|c|}
\hline & $\boldsymbol{Y}$ & $\boldsymbol{X}_{\mathbf{1}}$ & $\boldsymbol{X}_{\mathbf{2}}$ \\
\hline Nilai Rata-Rata & 889,95 & 420,87 & 10815,76 \\
\hline Nilai Maksimum & 2228 & 582 & 14802 \\
\hline Nilai Minimum & 287 & 176 & 8502 \\
\hline
\end{tabular}

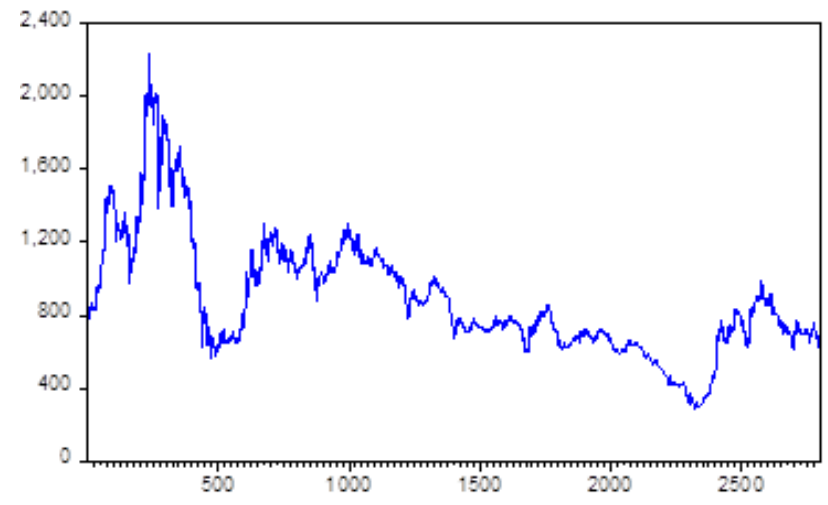

Gambar 1. Line Plot Harga Saham PT. ANTAM tbk

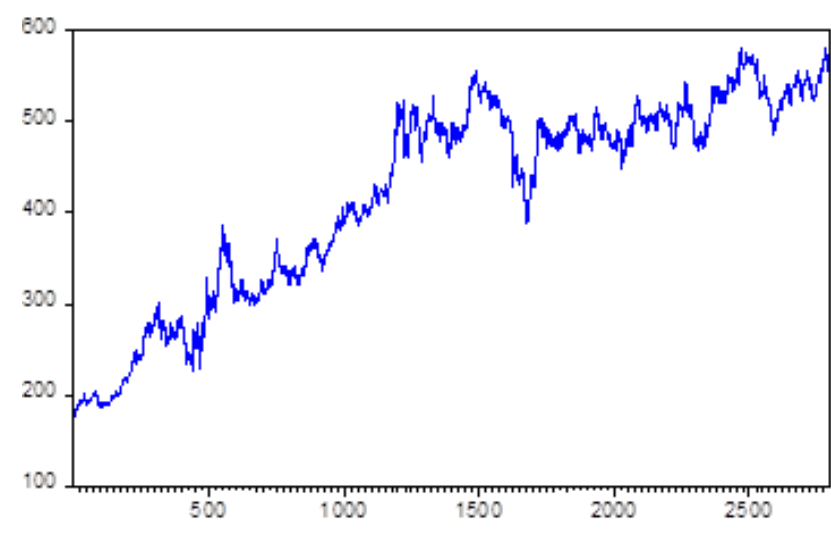

Gambar 2. Line Plot Harga Emas

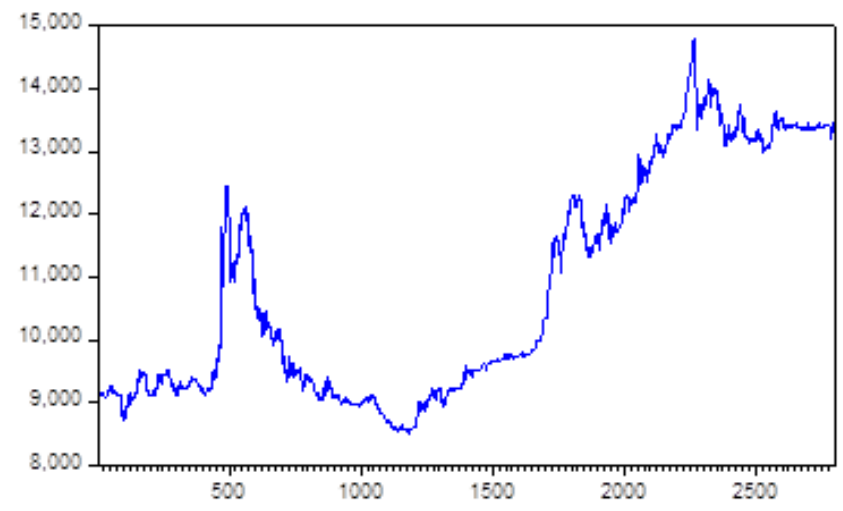

Gambar 3. Line Plot Harga Dolar 


\subsubsection{Stasioneritas Data Aktual}

Untuk pemeriksaan stasioneritas data dalam mean, uji statistik yang digunakan yakni uji Augmented Dickey-Fuller $(A D F)$. Uji ini bertujuan untuk mendeteksi akar unit dalam variabel-variabel yang digunakan. Dengan hipotesis yang digunakan dalam penelitian ini adalah :

$H_{0}$ : Terdapat akar-akar unit (data tidak stasioner)

$H_{1}$ : Tidak terdapat akar-akar unit (data stasioner)

Jika $A D F$ test statistic hitung lebih besar dari MacKinnon Critical Value 1\%, 5\%, dan $10 \%$ maka $H_{1}$ diterima dan $H_{0}$ ditolak. Dengan demikian dapat disimpulkan bahwa data tidak terdapat akar-akar unit sehingga data bersifat stasioner, dan juga sebaliknya. Berikut ini merupakan hasil uji akar unit menggunakan uji $A D F$ yang dimuat dalam Tabel 2.

Tabel 2. Uji Akar Unit

\begin{tabular}{ccccc}
\hline Variabel & Level & \multicolumn{3}{c}{ Differensi Pertama } \\
\cline { 2 - 5 } & Statistik Uji ADF & $\boldsymbol{p}$ value & Statistik Uji ADF & $\boldsymbol{p}$ value \\
\hline $\boldsymbol{Y}$ & $-1,8778$ & 0,3431 & $-53,4933$ & 0,0001 \\
$\boldsymbol{X}_{\mathbf{1}}$ & $-1,8251$ & 0,3685 & $-55,7873$ & 0,0001 \\
$\boldsymbol{X}_{\mathbf{2}}$ & $-0,6064$ & 0,8668 & $-54,9519$ & 0,0001 \\
\hline
\end{tabular}

Berdasarkan Tabel 2, diatas, dapat dilihat hasil uji akar unit menggunakan $A D F$ untuk masing-masing variabel pada kondisi level. Terlihat bahwa nilai statistik uji $A D F$ dari ketiga variabel harga saham $(Y)$, variabel harga emas $\left(X_{1}\right)$, dan variabel nilai tukar dolar terhadap rupiah $\left(X_{2}\right)$ lebih kecil dari MacKinnon Critical Value $1 \%$, 5\%, dan $10 \%$ (lampiran 3). Maka terima $H_{0}$ sehingga dapat dikatakan bahwa terdapat akar unit pada variabel-variabel tersebut. Dengan kata lain variabel harga saham $(Y)$, variabel harga emas $\left(X_{1}\right)$, dan variabel nilai tukar rupiah terhadap dolar $\left(X_{2}\right)$ tidak stasioner sehingga perlu dilakukan proses diferensi.

Selain itu pada Tabel 2, juga memperlihatkan hasil uji akar unit menggunakan uji ADF untuk masingmasing variabel pada kondisi diferensi pertama. Pada hasil uji akar unit diferensi pertama menunjukkan bahwa nilai statistik uji $A D F$ dari ketiga variabel $\left(Y, X_{1}, X_{2}\right)$ sudah lebih besar dari MacKinnon Critical Value $1 \%, 5 \%$, dan $10 \%$ (lampiran 3 ), maka tolak $H_{0}$, sehingga dapat dikatakan bahwa ketiga variabel tersebut sudah stasioner karena tidak terdapat akar unit.

Berdasarkan hasil pemeriksaan stasioneritas dari ketiga variabel $\left(Y, X_{1}\right.$, dan $\left.X_{2}\right)$ diatas diperoleh bahwa pada kondisi level $(I(0))$ ketiga variabel $\left(Y, X_{1}, X_{2}\right)$ belum stasioner atau belum terintegrasi. Kemudian semua variabel sudah stasioner atau terintegrasi pada kondisi diferensi pertama (I(1)). Sehingga hasil ini mengindikasikan bahwa model $A R D L$ dapat dibentuk dari variabel-variabel diatas.

\subsection{Data Hasil Transformasi Logaritma}

\subsubsection{Grafik Data Hasil Transformasi Logaritma}

Pada bagian ini membahas tentang data aktual yang ditransformasi kedalam bentuk logaritma. Hasilnya ditampilkan secara visual dalam bentuk grafik berikut ini.

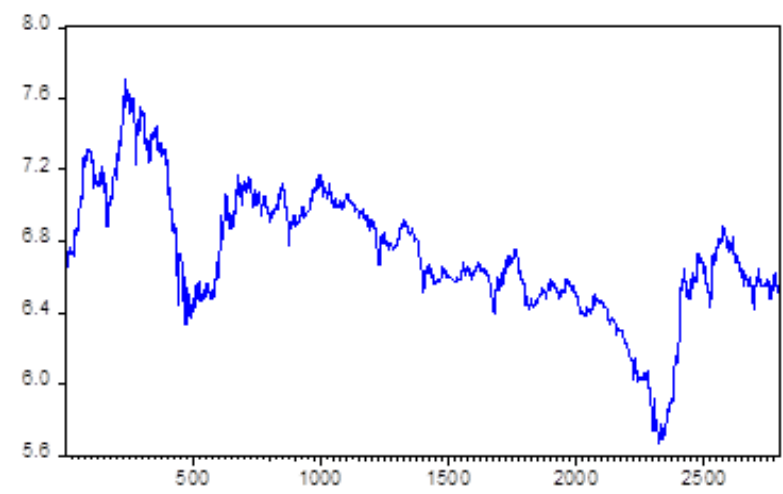

Gambar 4. Line Plot Log Data Harga Saham PT. ANTAM tbk 
Pada Gambar 4, dapat dilihat bahwa setelah dilakukan transformasi logaritma data harga saham PT. ANTAM tbk juga sangat bervariasi atau mengalami fluktuasi.

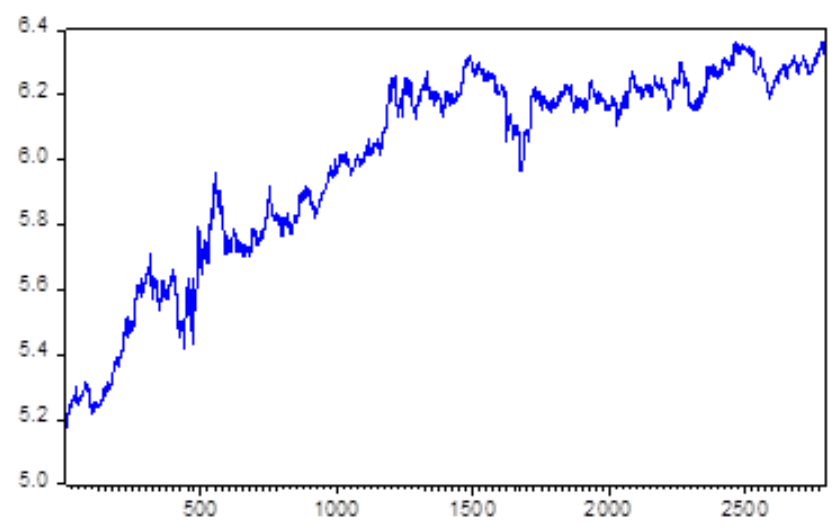

Gambar 5. Line Plot Log Data Harga Emas

Gambar 5, merupakan garfik data harga emas yang telah ditransformasi dalam bentuk logaritma. Pada gambar terlihat bahwa grafiknya mengalami fluktuasi.

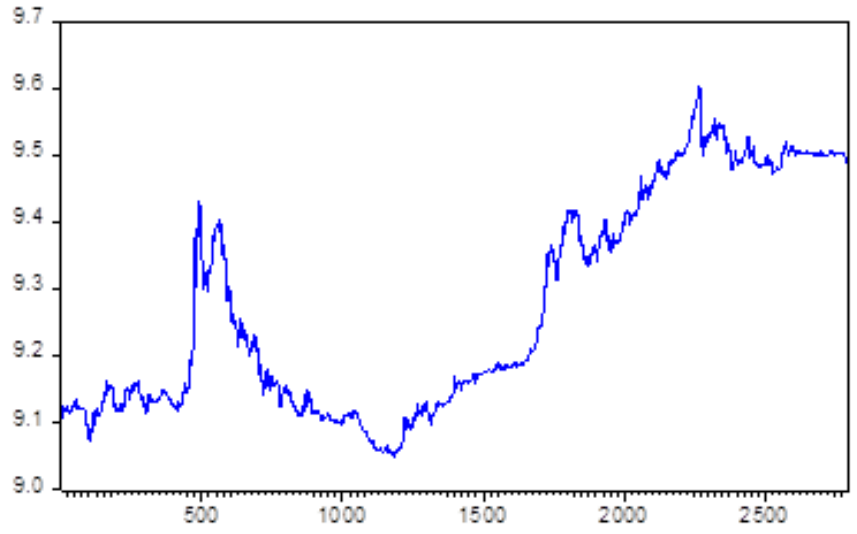

Gambar 6. Line Plot Log Data Harga Dolar

Selanjutnya Gambar 6, merupakan grafik data nilai tukar dolar terhadap rupiah yang telah ditransformasi kedalam bentuk logaritma. Secara visual dapat dilihat bahwa datanya sangat bervariasi atau mengalami fluktuasi.

\subsubsection{Stasioneritas Data Hasil Transformasi Logaritma}

Pada bagian ini, akan dibahas tentang uji stasioneritas data dalam bentuk mean dari ketiga variabel, yaitu variabel harga saham $(Y)$, variabel harga emas $\left(X_{1}\right)$, dan variabel nilai tukar dolar terhadap rupiah $\left(X_{2}\right)$ yang telah diubah kedalam bentuk transformasi logaritma. Uji stasioneritas pada bagian ini juga dilakukan dengan menggunakan uji statistik Augmented Dickey-Fuller (ADF). Dengan hipotesis yang sama yang digunakan pada uji stasioneritas sebelumnya pada data aktual. Secara ringkas hasilnya dirangkum dalam tabel berikut ini.

Tabel 3. Uji Akar Unit Dalam Log

\begin{tabular}{|c|c|c|c|c|}
\hline Variabel & Level & & Differensi Pertama & \\
\hline & Statistik Uji ADF & $\boldsymbol{p}$ value & Statistik Uji $\boldsymbol{A D F}$ & $\boldsymbol{p}$ value \\
\hline $\boldsymbol{l o g} \boldsymbol{Y}$ & $-1,6542$ & 0,4546 & $-53,2747$ & 0,0001 \\
\hline $\boldsymbol{\operatorname { l o g } \boldsymbol { X } _ { \mathbf { 1 } }}$ & $-2,3052$ & 0,1704 & $-54,6075$ & 0,0001 \\
\hline $\boldsymbol{\operatorname { l o g } \boldsymbol { X } _ { \mathbf { 2 } }}$ & $-0,5852$ & 0,8714 & $-55,8632$ & 0,0001 \\
\hline
\end{tabular}

Berdasakan Tabel 3, dapat dilihat uji stasioneritas data menggunakan uji $A D F$ untuk masing-masing variabel pada kondisi level. Nilai statistik uji $A D F$ untuk ketiga variabel $\left(\log Y, \log X_{1}\right.$, dan $\left.\log X_{2}\right)$ lebih kecil dari MacKinnon Critical Value 1\%, 5\%, dan $10 \%$ maka terima $H_{0}$. Hal ini menunjukkan bahwa ketiga 
variabel $\left(\log Y, \log X_{1}\right.$, dan $\left.\log X_{2}\right)$ tersebut memiliki akar unit atau tidak stasioner. Sehingga perlu dilakukan proses diferensi untuk ketiga variabel $\left(\log Y, \log X_{1}\right.$, dan $\left.\log X_{2}\right)$.

Selanjutnya pada Tabel 3, juga memperlihatkan hasil uji stasioneritas menggunakan uji ADF untuk masing-masing variabel pada kondisi diferensi pertama. Pada hasil uji stasioneritas diferensi pertama menunjukkan bahwa nilai statistik uji $A D F$ dari ketiga variabel $\left(\log Y, \log X_{1}\right.$, $\left.\operatorname{dan} \log X_{2}\right)$ sudah lebih besar dari MacKinnon Critical Value 1\%, 5\%, dan $10 \%$. Dengan demikian, maka terima $H_{1}$ dan tolak $H_{0}$, sehingga dapat dikatakan bahwa tidak terdapat akar unit pada ketiga variabel $\left(\log Y, \log X_{1}\right.$, $\left.\operatorname{dan} \log X_{2}\right)$ tersebut atau dengan kata lain bahwa ketiga variabel $\left(\log Y, \log X_{1}, \operatorname{dan} \log X_{2}\right)$ tersebut sudah stasioner.

Setelah melakukan pemeriksaan stasioneritas pada ketiga variabel $\left(\log Y, \log X_{1}, \operatorname{dan} \log X_{2}\right)$ yang datanya telah ditransformasi kedalam bentuk logaritma diperoleh bahwa pada kondisi level $(I(0))$ ketiga variabel $\left(\log Y, \log X_{1}\right.$, dan $\left.\log X_{2}\right)$ belum stasioner atau belum terintegrasi. Namun seteleh dilakukan proses diferensi, ketiga variabel $\left(\log Y, \log X_{1}\right.$, dan $\left.\log X_{2}\right)$ sudah stasioner pada kondisi diferensi pertama (I(1)). Hal ini menunjukkan hasil yang sama dengan uji staioneritas pada data aktual. Dengan demikian dapat dikatakan bahwa model $A R D L$ juga dapat dibentuk dari variabel-variabel tersebut.

\subsection{Seleksi Model}

Pada bagian seleksi model ini, akan dilakukan seleksi lag untuk dua tipe data, yaitu seleksi lag untuk data aktual dan seleksi lag untuk data yang telah ditransformasi kedalam bentuk logaritma. Seleksi lag ini dilakukan untuk memperoleh model terbaik dari kedua data tersebut. Dalam pemilihan model terbaik metode yang digunakan adalah metode AIC (Akaike's Information Criterion). Secara ringkas, hasil seleksi lag data aktual dan data hasil transformasi logaritma menggunakan AIC diperlihatkan seperti berikut ini.

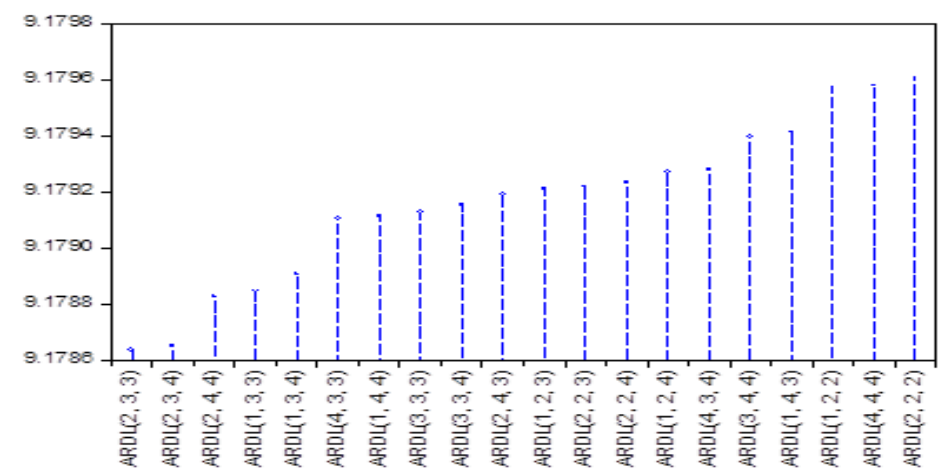

Gambar 7. Hasil Seleksi Lag Data Aktual

Gambar 7, menunjukkan hasil seleksi lag data aktual menggunakan AIC. Pada gambar tersebut terlihat bahwa semua nilai AIC positif, dimana nilai AIC terkecil adalah 9,1786, yang dimiliki oleh lag $(2,3,3)$. Dengan demikian, model terbaik untuk data aktual adalah model ARDL $(2,3,3)$.

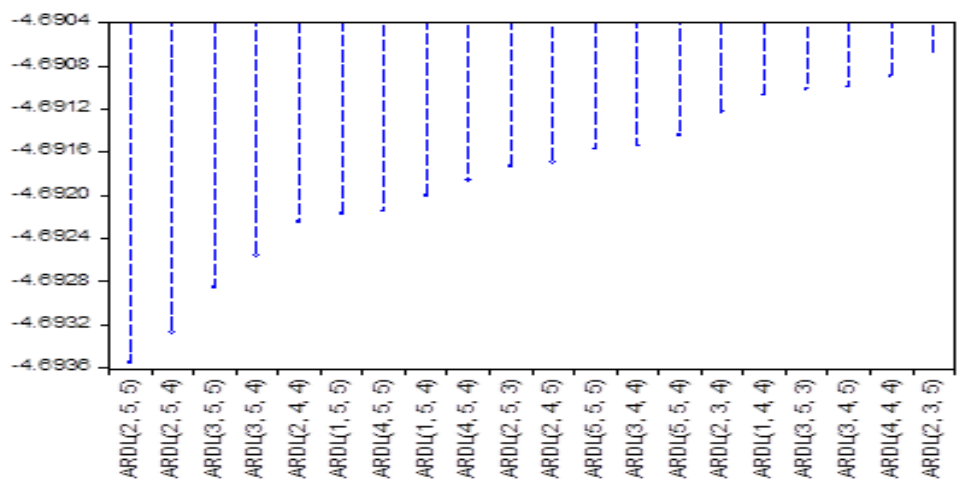

Gambar 8. Hasil Seleksi Lag Data Hasil Transformasi Logaritma

Pada Gambar 8, memperlihatkan hasil seleksi lag pada data transformasi logaritma menggunakan AIC. Gambar tersebut menunjukkan bahwa semua nilai AIC negatif, dimana nilai nilai AIC terkecil, yaitu 4,6936 pada lag $(2,5,5)$. Dengan demikian, model $A R D L(2,5,5)$ merupakan model terbaik untuk data transformasi logaritma. 
Berdasarkan hasil seleksi lag dari kedua tipe data tersebut, diperoleh bahwa nilai AIC untuk data transformasi logaritma lebih kecil dibandingkan data aktual. Dengan demikian, hasil seleksi model menggunakan $A I C$ menyatakan bahwa model $A R D L(2,5,5)$ untuk data transformasi logaritma lebih baik dibandingkan model $A R D L(2,3,3)$ untuk data aktual. Karena model yang terpilih merupakan model dari data hasil transformasi logaritma, maka untuk pengujian selanjutnya digunakan data hasil transformasi logaritma.

Bentuk umum model $A R D L(2,5,5)$ untuk data hasil transformasi logaritma yang akan diestimasi adalah:

$$
\begin{aligned}
\log Y_{t}= & \beta_{1} \log Y_{t-1}+\beta_{2} \log Y_{t-2}+\beta_{3} \log X_{1 t}+\beta_{4} \log X_{1 t-1}+\beta_{5} \log X_{1 t-2}+\beta_{6} \log X_{1 t-3}+\beta_{7} \log X_{1 t-4}+ \\
& \beta_{8} \log X_{1 t-5}+\beta_{9} \log X_{2 t}+\beta_{10} \log X_{2 t-1}+\beta_{11} \log X_{2 t-2}+\beta_{12} \log X_{2 t-3}+\beta_{13} \log X_{2 t-4}+ \\
& \beta_{14} \log X_{2 t-5}+\beta_{15}+e_{t}
\end{aligned}
$$

Dimana :

$\beta_{i} \quad$ : koefisien parameter model yang akan diestimasi.

$e_{t} \quad$ : residual model.

$i \quad: 1,2,3, \ldots, 15$.

\subsection{Estimasi Model ARDL(2,5,5) Untuk Data Hasil Transformasi Logaritma} berikut:

Hasil estimasi koefiisien parameter model $\operatorname{ARDL}(2,5,5)$ telah dirangkum dalam Tabel 4, sebagai

Table 4. Estimasi Parameter Model

\begin{tabular}{|c|c|c|c|}
\hline Variabel & Koefisien & Parameter & $p$ value \\
\hline $\log Y_{t-1}$ & $\beta_{1}$ & 0,9482 & 0,0000 \\
\hline $\log Y_{t-2}$ & $\beta_{2}$ & 0,0459 & 0,0158 \\
\hline $\log X_{1 t}$ & $\beta_{3}$ & 0,1775 & 0,0000 \\
\hline $\log X_{1 t-1}$ & $\beta_{4}$ & 0,0976 & 0,0627 \\
\hline $\log X_{1 t-2}$ & $\beta_{5}$ & $-0,1856$ & 0,0004 \\
\hline $\log X_{1 t-3}$ & $\beta_{6}$ & $-0,0106$ & 0,8394 \\
\hline $\log X_{1 t-4}$ & $\beta_{7}$ & 0,0171 & 0,7434 \\
\hline $\log X_{1 t-5}$ & $\beta_{8}$ & $-0,0992$ & 0,0075 \\
\hline $\log X_{2 t}$ & $\beta_{9}$ & $-0,7182$ & 0,0000 \\
\hline $\log X_{2 t-1}$ & $\beta_{10}$ & 0,3831 & 0,0010 \\
\hline $\log X_{2 t-2}$ & $\beta_{11}$ & 0,0617 & 0,5953 \\
\hline $\log X_{2 t-3}$ & $\beta_{12}$ & 0,0580 & 0,6165 \\
\hline $\log X_{2 t-4}$ & $\beta_{13}$ & 0,0735 & 0,5258 \\
\hline $\log X_{2 t-5}$ & $\beta_{14}$ & 0,1378 & 0,0958 \\
\hline$C$ & $\beta_{15}$ & 0,0962 & 0,0407 \\
\hline
\end{tabular}

Berdasarkan hasil estimasi parameter yang diperlihatkan pada Tabel 4, maka model ARDL(2,5,5) dapat ditulis dalam bentuk persamaan berikut ini:

$$
\begin{aligned}
& \log Y_{t}=0,9482 \log Y_{t-1}+0,0459 \log Y_{t-2}+0,1775 \log X_{1 t}+0,0976 \log X_{1 t-1}-0,1856 \log X_{1 t-2}- \\
& 0,0106 \log X_{1 t-3}+0,0171 \log X_{1 t-4}-0,0992 \log X_{1 t-5}-0,7182 \log X_{2 t}+0,3831 \log X_{2 t-1}+ \\
& 0,0617 \log X_{2 t-2}+0,0580 \log X_{2 t-3}+0,0735 \log X_{2 t-4}+0,1378 \log X_{2 t-5}+0,0962+e_{t}
\end{aligned}
$$

Selain estimasi parameter Tabel 4, juga memperlihatkan uji signifikansi parameter untuk setiap koefisien yang diperoleh pada persamaan model ARDL diatas, yakni $p$ value hasil uji t untuk setiap koefisien parameter model. Pada tabel tersebut diperlihatkan bahwa $p$ value untuk beberapa koefisien parameter, yaitu $\log Y_{t-1}, \log Y_{t-2}, \log X_{1 t}, \log X_{1 t-2}, \log X_{1 t-5}, \log X_{2 t}, \log X_{2 t-1}$, dan $C$ tidak melebihi nilai $\alpha=0,05$. Ini berarti bahwa pada taraf kepercayaan $95 \%$ beberapa koefisien parameter variabel independen secara signifikan mempengaruhi variabel dependen. 


\subsection{Pemeriksaan Diagnosa Model ARDL $(2,5,5)$ \\ 3.5.1 Uji Autokorelasi}

Pemeriksaan Autokorelasi yang diperoleh pada bagian ini menggunakan statistik uji Breusch-Godfrey Lagrange Multiplier (BGLM) dengan hipotesa yang digunakan yaitu.

$H_{0}$ : tidak terdapat autokorelasi pada residual model $A R D L(2,5,5)$.

$H_{1}$ : terdapat autokorelasi pada residual model $A R D L(2,5,5)$.

Berdasarkan hasil pengolahan data diperoleh bahwa $p$ - value statistik uji BGLM adalah 0,8894. Ini berarti bahwa pada taraf kepercayaan 95\% hipotesa $H_{0}$ diterima karena $p$ value statistik uji BGLM lebih besar dari nilai $\alpha=5 \%$. Dengan demikian, dapat dikatakan bahwa tidak terdapat masalah autokorelasi pada residual model ARDL $(2,5,5)$.

\subsubsection{Uji Stabilitas Model Comulative Sum (CUSUM)}

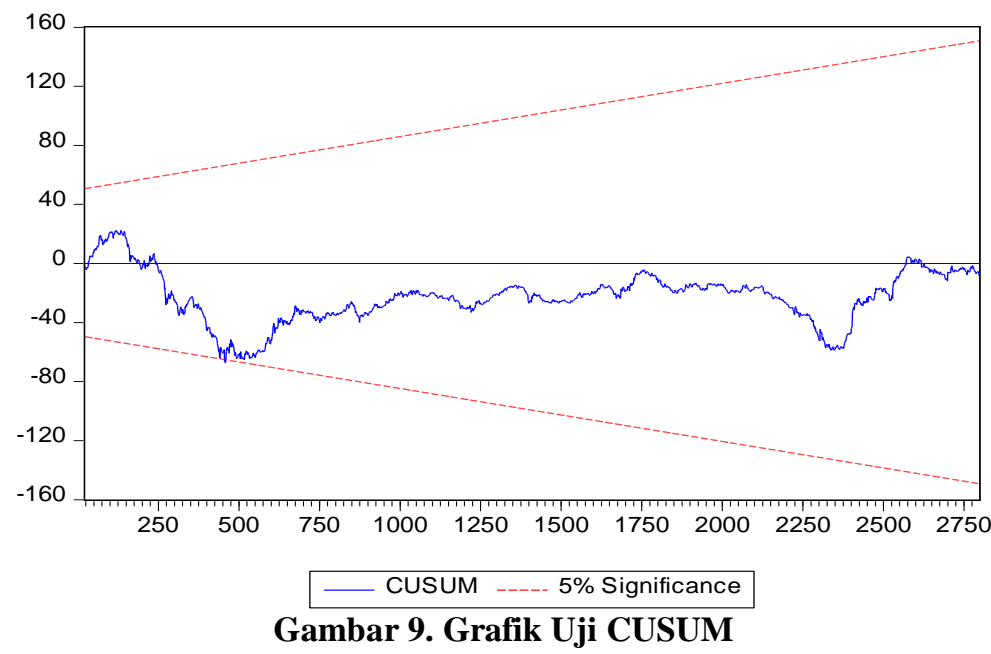

Berdasarkan Gambar 9, diatas dapat dilihat uji kestabilan model $A R D L(2,5,5)$ menggunakan Uji CUSUM dengan tingkat kepercayaan 95\%. Pada gambar telihat bahwa bentuk diagram garis solid berwarna biru yang berada diantara dua garis putus-putus berwarna merah yang merupakan kontrol kestabilan nilai-nilai CUSUM pada tingkat kepercayaan 95\%. Sehingga dapat disimpulkan bahwa model $A R D L(2,5,5)$ telah stabil.

\subsection{Uji Bounds Model ARDL(2,5,5)}

Uji Bounds (batas) ini dilakukan untuk mengetahui apakah terdapat hubungan jangka panjang (longrun relationship) dari variabel-variabel independen yang berpengaruh terhadap variabel dependen (harga saham) pada model $A R D L(2,5,5)$. Dengan hipotesis yang digunakan dalam uji ini adalah :

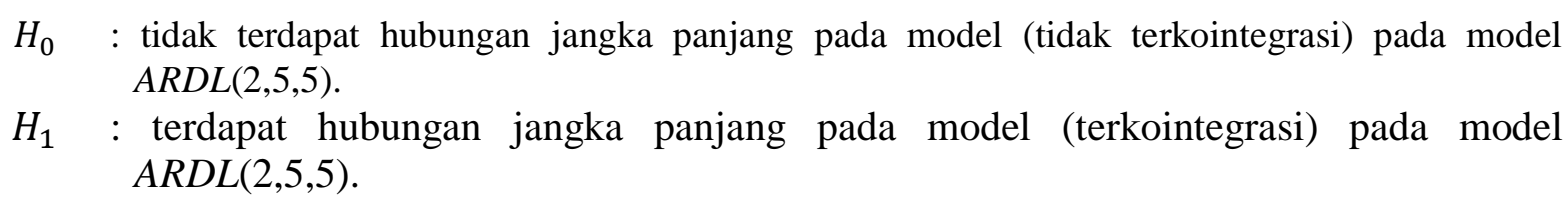

Hasil uji Bounds pada model ARDL(2,5,5) untuk beberapa tingkat kepercayaan diperlihatkan pada Tabel 5, dibawah ini.

Tabel 5. Uji Bounds Model ARDL(2,5,5)

\begin{tabular}{|c|c|c|}
\hline \multicolumn{2}{|c|}{ Nilai Statistik-F } & 2,6148 \\
\hline \multicolumn{3}{|c|}{ Nilai Kritis } \\
\hline Nilai $\alpha$ & Batas Bawah & Batas Atas (I(1)) \\
\hline $10 \%$ & 2,63 & 3,35 \\
\hline $5 \%$ & 3,1 & 3,87 \\
\hline $2,5 \%$ & 3,55 & 4,38 \\
\hline $1 \%$ & 4,13 & 5 \\
\hline
\end{tabular}


Berdasarkan pada Tabel 5, dapat dilihat bahwa nilai Statistik-F adalah 2,6148 dan nilai kritis uji Bounds untuk masing-masing tingkat kepercayaan 90\%, 95\%, 97,5\%, dan 99\%. Dari tabel diatas diperoleh bahwa nilai Statistik-F lebih kecil daripada nilai kritis batas bawah (lower bound), maka hipotesis nol diterima dan $H_{1}$ ditolak, sehingga dapat dikatakan bahwa tidak terdapat hubungan jangka panjang (tidak terkointegrasi) pada model $A R D L(2,5,5)$. Dengan demikian, dalam jangka pendek harga emas dan nilai tukar dolar terhadap rupiah mempengaruhi harga saham PT. ANTAM tbk

\subsection{Interpretasi Model}

Interpretasi model pada bagian ini dibahas berdasarkan hasil estimasi koefisien parameter model $A R D L(2,5,5)$ yang telah ditulis dalam bentuk persamaan model ARDL. Interpretasi model ini menjelaskan tentang hubungan dari setiap variabel independen, yakni variabel harga emas $\left(X_{1}\right)$ dan variabel nilai tukar dolar tehadap rupiah $\left(X_{2}\right)$ yang mempengaruhi harga saham PT. ANTAM tbk (dependen $Y$ ), dan juga pengaruh dari harga saham PT. ANTAM tbk (dependen $Y$ ) pada periode-periode sebelumnya terhadap harga saham PT. ANTAM tbk (dependen $Y$ ) saat ini.

Berdasarkan pada persamaan (4.2) dan hasil uji bounds diperoleh bahwa dalam jangka pendek harga saham PT. ANTAM tbk pada periode pertama dan kedua mempengaruhi harga saham PT. ANTAM tbk saat ini, yakni apabila harga saham PT. ANTAM tbk pada periode pertama mengalami kenaikan 1\%, maka harga saham PT. ANTAM tbk saat ini akan mengalami kenaikan sebesar 94\%, sedangkan apabila harga saham PT. ANTAM tbk pada periode kedua mengalami kenaikan 1\%, maka harga saham PT. ANTAM tbk saat ini mengalami kenaikan sebesar $4 \%$.

Selanjutnya dalam jangka pendek harga emas dan nilai tukar dolar terhadap rupiah juga sangat mempengaruhi harga saham PT. ANTAM tbk. Untuk harga emas, apabila harga emas pada periode sekarang mengalami kenaikan 1\%, maka akan mempengaruhi kenaikan harga saham PT. ANTAM tbk sebesar 1\%, sebaliknya pada periode kelima jika harga emas mengalami kenaikan 1\%, maka akan mempengaruhi penurunan harga saham PT. ANTAM tbk sebesar 9\%. Sedangkan untuk nilai tukar dolar terhadap rupiah, jika pada periode sekarang nilai tukar dolar terhadap rupiah mengalami kenaikan 1\%, maka akan mempengaruhi kenaikan harga saham PT. ANTAM tbk sebesar 7\%. Kemudian pada periode pertama kenaikan nilai tukar dolar terhadap rupiah sebesar 1\%, akan mempengaruhi kenaikan harga saham PT. ANTAM tbk sebesar 38\%.

\section{Kesimpulan}

Dari hasil penelitian dan analisis yang telah dilakukan maka dapat disimpulkan bahwa:

1. Model yang diperoleh adalah model $\operatorname{ARDL}(2,5,5)$ dengan nilai nilai $A I C$ terkecil, yaitu $-4,6936$. Modelnya adalah seperti berikut.

$$
\begin{aligned}
\log Y_{t}=0,9482 & \log Y_{t-1}+0,0459 \log Y_{t-2}+0,1775 \log X_{1 t}+0,0976 \log X_{1 t-1}-0,1856 \log X_{1 t-2} \\
& -0,0106 \log X_{1 t-3}+0,0171 \log X_{1 t-4}-0,0992 \log X_{1 t-5}-0,7182 \log X_{2 t} \\
& +0,3831 \log X_{2 t-1}+0,0617 \log X_{2 t-2}+0,0580 \log X_{2 t-3}+0,0735 \log X_{2 t-4} \\
& +0,1378 \log X_{2 t-5}+0,0962+e_{t}
\end{aligned}
$$

2. Dari hasil pengujian Bounds pada model $A R D L(2,5,5)$ tidak terdapat hubungan jangka panjang (long run) antara harga saham PT. ANTAM tbk dengan faktor harga emas dan nilai tukar dolar terhadap rupiah. Hal ini dapat dilihat dari nilai Statistik-F, yaitu 2,6148 yang lebih kecil daripada nilai kritis batas bawah (lower bound) untuk masing-masing tingkat kepercayaan 90\%, 95\%, 97,5\%, dan 99\% maka $H_{0}$ diterima. Dengan demikian, dalam jangka pendek harga emas dan nilai tukar dolar terhadap rupiah mempengaruhi harga saham PT. ANTAM tbk. 


\section{Daftar Pustaka}

[1] H. Suad, "Manajemen Keuangan,” 4th penyunt., Yogyakarta, BPFE, 2008.

[2] D. N. Gujarati dan D. C. Porter, "Dasar-dasar Ekonometrika,” 5th penyunt., Jakarta, Salemba Empat, 2013.

[3] N. I. Pradasari, F. T. P. W. dan D. Triyanto, "Aplikasi Jaringan Saraf Tiruan untuk memprediksi Penyakit Saluran Pernapasan dengan Metode Backpropagation,” Jurnal Coding Sistem Komputer Untan, vol. 1, no. 1, 2013.

[4] D. N. Gujarati, "Basic Econometrics," 4th penyunt., New York, McGraw-Hill Companies, Inc., 2003.

[5] N. Jatiningrum, "Model Dinamis : Autoregressive dan Distribusi Lag,” Yogyakarta, 2008.

[6] H. Suad, "Manajemen Keuangan," 4th penyunt., Yogyakarta, BPFE, 2008.

[7] D. Nachrowi dan U. Hardius, Penggunaan Teknik Ekonometrika, Jakarta: PT. Raja Grafindo Parsada, 2002.

[8] W. Enders, Applied Econometric Time Series, New York: John Willey and Sons, Inc, 2004.

[9] D. N. Nachrowi, Pendekatan Populer dan Praktis Ekonometrika untuk Analisis Ekonomi dan Keuangan, Jakarta: Fakultas ekonomi Universitas Indonesia, 2006.

[10] I. Z. Alwi, Pasar Modal Teori dan Aplikasi, jakarta: Yayasan Pancur Siwah, 2008.

[11] Wei dan W. S. Wiliam, Time Series Analysis Univariate and Multivariate, Addison-Wesley Publishing Company, 1990.

[12] H. M, S. Yongcheol dan J. S. Richard, Bound Testing Approachs to The Analysis of Level Relationship, Cambridge: University of Cambridge, 2001.

[13] J. Supranto, Ekonomika I, Jakarta: LPFE VI Jakarta, 1989.

[14] J. Supranto, Ekonometrika II, Jakarta: LPFE-UI, 1995. 